\title{
The New Deal
}

The Depression Years, 1933-40 


\section{Related Titles}

Regions and Regionalism in the United States

Michael Bradshaw

American Women Since 1945

Rochelle Gatlin

The American Revolution

Colin Bonwick

American Public Policy: Promise and Performance, 2nd Edition Guy Peters 


\section{The New Deal \\ The Depression Years, 1933-40}

Anthony J. Badger 


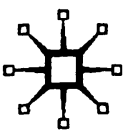

- Anthony J. Badger 1989

All rights reserved. No reproduction, copy or transmission of this publication may be made without written permission.

No paragraph of this publication may be reproduced, copied or transmitted save with written permission or in accordance with the provisions of the Copyright, Designs and Patents Act 1988, or under the terms of any licence permitting limited copying issued by the Copyright Licensing Agency, 90 Tottenham Court Road, London W1T 4LP.

Any person who does any unauthorised act in relation to this publication may be liable to criminal prosecution and civil claims for damages.

The author has asserted his right to be identified as the author of this work in accordance with the Copyright, Designs and Patents Act 1988.

Published by

PALGRAVE MACMILLAN

Houndmills, Basingstoke, Hampshire RG21 6XS and

175 Fifth Avenue, New York, N. Y. 10010

Companies and representatives throughout the world

PALGRAVE MACMILLAN is the global academic imprint of the Palgrave Macmillan division of St. Martin's Press, LLC and of Palgrave Macmillan Ltd. Macmillan ${ }^{\oplus}$ is a registered trademark in the United States, United Kingdom and other countries. Palgrave is a registered trademark in the European Union and other countries.

ISBN 978-0-333-28904-4 ISBN 978-1-349-18848-2 (eBook)

DOI 10.1007/978-1-349-18848-2

This book is printed Logging, pulping and manufacturing processes are expected to conform to the environmental regulations of the country of origin.

A catalogue record for this book is available from the British Library. Transferred to digital printing 2002 
For Ruth 


\section{Contents}

Acknowledgements $\quad$ ix

Introduction 1

1 Depression America 11

2 Holidays, Eagles, and Deficits:

3 Strife and Satisfaction: Labour 118

4 Parity and Poverty: Agriculture 147

5 Doles and Jobs: Welfare 190

6 Partial Realignment: Politics 245

Conclusion: Unanticipated Consequences 299

Bibliographical Essay $\quad 313$

List of Abbreviations $\quad 365$

Index $\quad 367$ 


\section{Acknowledgements}

My purpose is to interpret a substantial secondary literature on the New Deal. The many debts I have incurred in writing this book are entirely disproportionate to its modest aim. It is nevertheless a pleasant duty to acknowledge them.

My first obligation is to all those scholars whose work I have ransacked. To those who may feel that I have inadequately acknowledged their contribution or that I have distorted what they wrote, I can only plead inadvertence. My accomplices have been the unfailingly efficient Inter-Library Loan staff of Newcastle University Library, without whose assistance I could never have contemplated writing this book.

The book originated in a special subject course on the New Deal which I taught in Newcastle from 1974 to 1984 . I am indebted to all the students who worked together with me to teach ourselves about the 1930s. I owe a special debt to the graduates of 1982 and 1984.

At an early stage I participated in an intensive symposium on the New Deal at the David Bruce Centre at the University of Keele. The other participants will recognise their contributions all too clearly in the pages that follow. David Adams organised and hosted the symposium with characteristic efficiency and generosity. Soon afterwards, a fellowship from the American Council of Learned Societies enabled me to start putting my ideas down on paper. The friendship and hospitality of Dan and Jane Carter at Emory University gave me the perfect environment to do so.

Invitations, first from Bruce Collins and Rhodri Jeffreys-Jones, then from Stephen Baskerville and Ralph Willett, to contribute to collections of essays gave me a much-needed opportunity to find out what I really thought about local studies of the New Deal and about Huey Long. Maldwyn Jones invited me to respond to the 


\section{x Acknowledgements}

1986 Commonwealth Lecture. John L. Thomas's brilliant lecture 'The Road Not Taken: Perspectives on Post-Frontier America, 1920-1940' made me explore aspects of the 1930s that I had hitherto resolutely ignored.

I have been fortunate in having friends who have not entirely allowed affection to cloud their critical faculties. Howell Harris has taught me all I know about organised labour and has acted as an instant bibliographical guide on everything. Bill Speck strove to excise the worst solecisms. Stephen Baskerville attempted in vain to make me understand economic thought. Bob Reinders put me right on social workers and on much else besides by meticulously scrutinising the whole manuscript. Jim Patterson, who more than anyone has influenced my work over the past twenty years, unerringly exposed great expanses of sloppy thinking and expression. The errors that remain despite their best endeavours are testimony to my own obstinacy.

Many others have helped this project, sometimes unwittingly, notably Malcolm Call, Stephen Constantine, Charlotte Erickson, Peter Fearon, John Harper, Michael Heale, Paul Metcalfe, Iwan Morgan, Jack Pole, Jim Potter, John Rowett, David Saunders, Patricia Sullivan, and Philip Taylor.

I have sorely tried the patience of Sarah Mahaffy, Vanessa Couchman, and Vanessa Graham as editors. The delivery dates I promised them usually proved as chimerical as Roosevelt's balanced budgets. Nevertheless, they did not allow me to give up. At a late stage, Arthur Wang made many consistently helpful suggestions.

Janice Cummin and Julie Savage typed assorted drafts with a speed, accuracy, and good humour that belied the pressure imposed on them by my illegibility and tardiness.

Finally, I want to acknowledge two personal debts. I only hope that this book in a small way repays the many kindnesses Alger Hiss and Isabel Johnson have shown me. It is customary for academics to acknowledge long-suffering partners. Those who know Ruth will know that she has not suffered in silence. Suffice it to say that without her love, tolerance, and constant encouragement this book would never have been completed. I dedicate it to her. 